\title{
Perceptions of Students' Learning Critical Thinking through Debate in a Technology Classroom: A Case Study
}

Sophia Scott

Abstract

Critical thinking is often a desired competency for graduates of a technology program. Organizational members have uttered concern about students' inability to think critically. Although traditional pedagogical techniques, such as lectures and examinations, center on knowledge acquisition, debates in the technology classroom can effectively facilitate critical thinking. The purpose of this study was to gather via questionnaires the perceptions of technology students on the debate process used in the classroom to increase critical thinking. Overall, the students believed that the debate process w as a useful learning activity. The results of the questionnaire revealed that students believed that the debates helped them understand the topic better, learn new knowledge, and gain an understanding of the debate process. In addition, students thought that the debates increased their critical thinking skills.

\section{Introduction}

Employers value employees who can solve complex problems, communicate effectively, and think critically (Gokhale, 1995). A function of higher education is to teach students to think. University accreditation boards, for example, the National Association of Industrial Technology (NAIT), the Accreditation Board of Engineering and Technology (ABET) and the Inter national Technology Education Association (ITEA) recognize competencies such as problem solving, communication, and teamwork (including critical thinking) in their accreditation criteria (NAIT, 2007; ABET, 2007; \& ITEA, 2007). Despite the emphasis on these competencies, businessmen and businesswomen have expressed concern with students' inability to integrate competencies, for example, teamwork, communication, and oral presentation skills with critical thinking (Roy \& Macchiette, 2005).

Bissell and Lemons (2006) ascertained that faculty who teach at universities in a technology or engineering curriculum consider critical thinking a primary objective. It is a sad truth that the "average" college student does not think critically, and not all courses include critical thinking.
Technology professors in higher education tend to focus on teaching discipline-specif ic content knowledge, but often they struggle with the time and resources needed to design effective strategies in order to teach critical thinking (Goodwin, 2003). Although traditional pedagogical techniques such as lectures and examinations center on knowledge acquisition, debates in the classroom can effectively facilitate critical thinking (Roy \& Macchiette, 2005). Therefore, debate as a teaching tool, has a place in pedagogical methods because it allows students to enhance critical thinking through investigating arguments, engaging in research, gathering information, performing analysis, assessing arguments, questioning assumptions, and demonstrating interpersonal skills.

\section{Purpose}

Initially, the researcher used debate in a Science, Technology, and Society course as a tool to introduce an experiential learning opportunity. The main objective of the course was to use a selection of modern topics in science and technology to increase communication and critical-thinking skills. Debate was a natural fit for the course because the topics were tied to current events, and students were allowed to critically analyze a controversial topic while practicing other competencies like writing, presenting information and higher level thinking. Because the debate was a new experience for the students, it was essential to learn their perceptions of the debate process by asking the following questions:

1. What was their perception of the debate process in a technology classroom?

2. Did they believe the debates increased their critical-thinking ability?

This study highlights the procedure the researchers used in implementing debates in the technology classroom. In addition, the perceptions of technology students will be discussed.

\section{Review of Literature}

How can professors transform the student from a passive learner to an active learner? The 
typical college classroom used to be dominated by the passive learning strategy, lecture. In university classrooms, professors now implement active learning strategies, such as discussions, role playing, case studies, and debate. Vo and Morris (2006) used debate to supplement the traditional lecture by engaging the learner. Debate also allows professors to create an environment that helps students move away from just receiving knowledge into an atmosphere of active participation. Additionally, debating contemporary issues in the technology classroom can be an invaluable tool for encouraging critical thinking (Dickson, 2004).

\section{Defining Critical Thinking}

Halpern (1996) characterized critical thinking as the use of co gnitive skills or strategies to increase the probability of a desirable outcome. Critical thinking also involves evaluating reasoning and factors considered in making decisions. According to Paul and Elder, (2006) a well-cultivated critical thinker solves a complex problem by raising vital questions, gathering relevant information, determining findings, and communicating effectively. Maiorana (1992) noted that the purpose of critical thinking is to use questioning techniques to achieve understanding, evaluate view-points, and solve problems. The debate process can also help student's master content. This researcher believes that using debate as a teaching tool helps students de velop specific skills (i.e., analyzing, synthesizing and evaluating supported arguments). In addition, the debate process incorporates critical thinking and a plethora of other skills including, listening, researching, problem solving, reasoning, questioning, and communicating.

\section{Evaluating Critical Thinking}

Scientific thinkers seek to quantify, explain, and predict relationships. It is reasonable to conclude that science and technology courses are a good place to learn critical thinking by using the scientific thinking (Schafersman, 1991). The scientific method involves asking questions, researching information, developing questions, testing, analyzing, and communicating results. All of these involve different levels of critical thinking (Paul \& Elder, 2006). Brookfield (1997) believes that critical thinking can be analyzed in terms of process and purpose. The very process of debate allows students to recognize the assumptions that underline their thoughts and actions. There are many ways that critical thinking has been assessed in the classroom, including using pre- and posttests, case studies, storytelling, questioning, role playing, and debates.

Another way to evaluate critical thinking is through classification. Bissell and Lemons (2006) consider Bloom's taxonomy the way to categorize critical thinking in the classroom. Bloom, Englehart, Furst, Hill, and Krathwohl (1956) developed a classification for learning. This classification can be used to evaluate critical thinking using six levels of cognitive thinking. The debate exercise modules in this study have been developed using Bloom's Taxonomy (see Table1).

Students progress through the levels of the taxonomy from lowest to highest. Although critical thinking exist at every level, higher order thinking occurs at the synthesis and e valuation level.

\section{Use of Debate in the Technology Classroom}

Debates in science and technology classes can help the students explore topics that affect society. Proulx (2004) used debate in the class room for analyzing, testing, and evaluating arguments. Vo \& Morris (2006) also found that debate increased the benefits of the traditional lecture by engaging the learner in the material. Additionally, Osborne (2005) established that debate in the classroom is effective in helping

\section{Table 1 Bloom's Taxonomy}

\begin{tabular}{|ll|}
\hline Category & Description \\
\hline Knowledge & Ability to recall previously learned material. \\
\hline Comprehension & Ability to grasp meaning, explain, restate ideas. \\
\hline Application & Ability to use learned material in new situations. \\
\hline Analysis & $\begin{array}{l}\text { Ability to separate material into component par ts } \\
\text { and show relationships between parts. }\end{array}$ \\
\hline Synthesis & $\begin{array}{l}\text { Ability to put together the separate ideas to for m } \\
\text { new whole, establish relationships. }\end{array}$ \\
\hline Evaluation & Ability to judge the worth of material against stated criteria. \\
\hline
\end{tabular}


students learn a discipline and demonstrate the ability to read and write critically. The ability to write effective arguments influences success of students in preparation for their future careers.

Dickson (2004) declared that the debate process assessed the student's ability to write effectively, work in teams, and analyze arguments, all of which can improve the ability to think critically. Critical thinking that includes debate also allows for collaboration. Collaborative teams can achieve higher levels of thinking through the use of persuasive evidence. This collaboration allows individuals to retain information longer and the opportunity to engage in discussion and shared learning (Gokhale, 1995). Lewis and Wakefield (1983) emphasized individual learning, as well as, team formal and extemporaneous speaking in the debate process.

Walker and Warhust (2000) claimed that debates in the classroom have been effective in increasing critical thinking by letting students to connect as they learn subject knowledge. In their classes, they found that $82 \%$ of students thought that they understood the subject matter, and $85 \%$ believed that they learned something valuable. In addition, debates boosted the analytical problem solving, communication, presentation and the ability to form teams. Moeller (1985) found that while many students were apprehensive about the debates, the process proved to be valuable and helped them in increasing their criticalthinking skills. Goodwin (2003) used debate to help students master the content in the class and asked students their perception of the debate process in the classroom. Several students commented on the unfamiliarity of the debate process and that the debate was uncomfortable. A majority of the students responded that the debate process was useful in gaining disciplinary knowledge and this process helped them with analyzing and presenting arguments. Students also replied that classroom debates helped them to recognize and deal with various points of view and improved their critical thinking.

\section{The Debate Process}

Traditional debates take many formats. The most common classroom debate is traditional debate (Ericson, Murphy \& Zeuschner, 2003). The debate process in this study star ted with the central resolution. Such a resolution is a declara tive statement that the team will either suppor $t$ or oppose. The affirmative team supports the resolution, and the negative team opposes it. The students built a case for the resolution (the case brief) in which they try to prove or disprove the resolution through evidence. In utilizing debate in the classroom, the professor should take an active role in coordinating the planning it (Roy $\&$ Macchiette, 2005). He or she should distinguish the debate brief from other for ms of written reports and stress the persuasion needed in the debate speeches. The debate process involved planning and considerable time spent preparing the students for the for mal debates. Students need to understand the debate process and terminology. There are several debate guides to help explain the debate process (Ericson, Murphy, \& Zeuschner, 2003). Additionally, Roy and Macchiette (2005) emphasized that the professor should seek responses from the students and that evaluation can be conducted in a variety of ways.

\section{Methods}

This study investigated students' perceptions of the debate process used in a technolo gy classroom to increase critical thinking.

\section{Subjects}

The study included 111 students enrolled in a Science, Technology, and Society course in the fall and spring of 2005-2006. The course was taught by two professors. The students performed one debate during the semester in which they participated in the course and they were asked to fill out a questionnaire authored by the researcher.

\section{Procedure}

The procedure for the research included the following steps:

\section{Preparing students for the debates.}

Students were divided into teams of four and given a resolution (see Table 2). The students were introduced to the debate process and were given an assignment sheet that outlined the debate process and instructions on preparing the case brief. The Appendix includes an example of a case brief. Students had time in and out of the classroom to prepare for the debates.

2. Performance of the debates. The students performed the debates. The students were then assessed on the quality of the debates. 
Table 2 Debate Resolutions

\begin{tabular}{|ll|}
\hline Debate & Resolutions \\
\hline One & Resolved: the United States should allow new embryonic stem cell research \\
\hline Two & Resolved: the United States should allow human cloning for research pur poses \\
\hline Three & $\begin{array}{l}\text { Resolved: the United States should allow monies to be exchanged for human organs for } \\
\text { transplant patients }\end{array}$ \\
\hline Four & Resolved: the United States should re gulate content on the Internet for minors \\
\hline Five & Resolved: the United States should adopt a flat income tax \\
\hline
\end{tabular}

3. Students filled out the questionnaire.

Following all of the debates, the students w ere asked to sign a consent for $m$ and asked to fill out the questionnaire.

\section{Findings}

Question 1: What was the student's perception of the debate process in a technology classroom?

The student questionnaire consisted of nine questions using a four-point Likert scale (1 =strongly disagree, $4=$ strongly agree). There was one open-ended question on the students' opinion of the debate process. Table 3 provides the question and the mean response from the students. critical thinking skills (3.16). It was important to the researcher to get the student perception of the debate process by allowing an open response question. Students commented that they enjoyed the debate process and that it was a good experience. Many class members thought the debates were challenging. Some of the students did not like speaking in front of the class or tr ying to defend their cases. Other students commented on the debate process as a good tool for w orking in teams and thinking critically.

\section{Discussion and Implications}

Debate in the technology classroom can yield great learning for the student. Debate as a teaching strategy allowed active learning on the student's part; it also allowed the students to

Table 3 Mean Score of Student Responses

\begin{tabular}{|ll|}
\hline Question & $M$ \\
\hline I learned new knowledge about the topic I debated & 3.53 \\
\hline I gained an understanding of the topic area of m y debate & 3.42 \\
\hline I felt comfortable explaining my position in the debate & 2.95 \\
\hline Writing the case brief helped me to break the infor mation into manageable parts & 3.11 \\
\hline The debates helped me know the difference between fact and opinion & 2.94 \\
\hline I was able to defend my position in the debate & 2.99 \\
\hline $\begin{array}{l}\text { I was able to gain additional knowledge on subjects that I was not aware of by } \\
\text { listening to the debates }\end{array}$ & 3.29 \\
\hline The debate process helped me increase my critical- thinking skills & 3.16 \\
\hline I prefer to prepare a debate rather than to tak e a test & 3.04 \\
\hline Total & 3.16 \\
\hline
\end{tabular}

The results of the questionnaire revealed that students believed that the debates helped them to learn new knowledge (3.53), to gain an understanding of the topic (3.42) and to $g$ ain additional knowledge on the subject (3.29). Students replied that they would rather prepare for a debate than take a test (3.16).

Question 2: Did students believe the debates increased their critical-thinking ability?

Students were asked if they felt that the debates increased their critical thinking. Students believed that debates did increase their demonstrate different levels of critical thinking. Students learned through the process of preparing the debate, performing the debate, listening to debates, and discussing the debate. Favorable outcomes of debates observed by the researcher included collaborative learning and higher order thinking. Because debate is being used in the classroom in a pedagogical manner, a structured debate with assessment was used. The experience with debates in the technology classroom was largely positive. Weaknesses were observed in the student's writing. Additionally, students lacked research and reasoning skills. In the debate speeches, students also often lack ed 
confidence and questioning skills.

Debate can be challenging in the technology classroom. Students may reject a different teaching strategy used to learn critical thinking. Most students were highly satisfied with the debate process and felt that the debates increased their critical-thinking skills. However, some students did not enjoy the debate process. Despite this minor issue, a science and technology course is an excellent environment to increase critical thinking through the use of debates.

\section{Summary and Conclusions}

Integrating critical thinking with other needed competencies like teamwork and communication is a worthwhile activity for the technology classroom. The debate process can be useful in gaining disciplinary knowledge and helping students with analyzing and presenting arguments. Furthermore, debate as a teaching tool, has a place in pedago gical methods because it allows students to enhance critical thinking through investigating arguments, engaging in research, gathering information, performing analysis, assessing arguments, questioning assumptions, and demonstrating inter- personal skills. Debate is a great supplement to the traditional lecture class because it eng ages the learner in the material. Debate also allows professors to create an environment that helps students move away from just receiving knowledge into an environment of active participation. Additionally, debating contemporary issues in the technology classroom can be an invaluable tool for encouraging critical thinking.

The results of this study only reflect experiences in this course and are not meant to provide evidence of student learning on critical thinking. According to this research, there is merit in debate as a teaching strate gy. More research should be conducted in the area using debate in the technology classroom to increase critical thinking. In conclusion, preparing, g rading, and evaluating the debate process can be time consuming, but may be worth pursuing in the technology classroom.

Dr. Sophia Scott is an Assistant Professor in the Department of Industrial and Engineering Technology at Southeast Missouri State University, Cape Girardeau, and is a Member at-large of Epsilon Pi Tau.

\section{References}

ABET (2007). The Engineering Accreditation Commission of the Accreditation Board of Engineering and Technology. Accreditation handbook online. Available at: http://www.abet.org.

Bissell, A. N. \& Lemons, P. P. (2006). A new method for assessing critical thinking in the classroom. BioScience. 56(1). 66-72.

Bloom, B. S., Englehart, M.D., Furst. E. J., Hill W.H. and Krathwohl, D. R. (1956). Taxonomy of educational objectives: The classification of educational goals, handbook 1 co gnitive domain. New York: McKay.

Brookfield, S.D. (1997). Assessing critical thinking. New Directions For Adults and Continuing Education. No. 75, Fall. Jossey-Bass Publishers. Pp. 17-29.

Dickson (2004). Developing "Real-world intelligence": Teaching argumentative writing through debate. English Journal. 94(1). 34-40.

Ericson, Murphy \& Zeuschner. (2003). The debater's guide. (3rd ed). Carbondale: Souther n Illinois University Press.

Gokhale, A, A (1995). Collaborate learning enhances critical thinking. Journal of Technology Education. 7(1).

Goodwin, J. (2003). Students' perspectives on debate exercises in content area classes. Communication Education. 52(2). 157-163.

Halpern, D. F. (1996) Thought and Knowledge: An Introduction to Critical Thinking. Mahwah, NJ: L. Erbaum Associates.

ITEA (2007). International Technology Education Association. Available: http://www.iteaconnect.org.

Lewis, L. M \& Wakefield J. A. (1983). Teaching psychology through an instructor-debate format. Teaching of Psychology. 10(2). 115-119. 
NAIT. (2007) Industrial Technology Accreditation Handbook On-line. Michigan: The National Association of Industrial Technology (NAIT). http://www.nait.org.

Maiorana, V. P. (1992). Critical Thinking Across the Curriculum: Building the Analytical Classroom. Bloomington, IN: Eric Clearinghouse.

Moeller, T. G. (1985). Methods and techniques: Using classroom debates in teaching de velopmental psychology. Teaching of Psychology 12(4). 207-209.

Osborne, A. (2005). Debate and student de velopment in the history classroom. New Directions for Teaching \& Learning. 103. 39-50.

Paul, R. \& Elder, L (2006). The Miniature Guide to Critical Thinking Concepts and Tools. Dillion Beach CA: The Foundation for Critical Thinking.

Proulx, G. (2004). Integrating scientific method and critical thinking in classroom debates on en vironmental issues. The American Biology Teacher. 66(1). 26-33.

Roy, A., \& Macchiette, B. (2005). Debating the is sues: A tool for augmenting critical thinking skills of marketing students. Journal of Marketing Education. 27(3). 264-276.

Schafersman, S. D. (1991) An introduction to critical thinking. Accessed Mar 26, 2007. Available online at http://www.freeinquiry.com/critical-thinking.html

Vo, H. X. \& Morris, R. L. (2006) Debate as a tool in teaching economics: Rationale, technique, and some evidence. Journal of Education for Business. 315-320.

Walker, M. \& Warhurst, C. (2000). "In most classes y ou sit around very quietly at a table and get lectured at...”: Debates, assessment and student lear ning. Teaching in Higher Education 5(1). 33-49.

\section{Appendix Case Brief Example}

Introduction (catch the audience attention)

Resolution:

Terms to define

Contention 1:

Evidence

Reasoning

Contention 2:

Evidence

Reasoning

Inherency (the need or lack of need for a plan)

Plan:

How plan will help with the resolution:

Conclusion: 